\title{
Bartolosides E-K from a Marine Coccoid Cyanobacterium
}

Tiago B. Afonso, ${ }^{\dagger, \ddagger \S}$ M. Sofia Costa, ${ }^{\dagger, \perp}$ Roberta Rezende de Castro, ${ }^{\prime}$ Sara Freitas, ${ }^{\dagger}$ Artur Silva," Maria Paula Cruz Schneider, " Rosário Martins, ${ }^{\dagger, \#}$ and Pedro N. Leão*, ${ }^{*}$

${ }^{\dagger}$ Interdisciplinary Centre of Marine and Environmental Research (CIIMAR/CIMAR), University of Porto, Terminal de Cruzeiros do Porto de Leixões, Avenida General Norton de Matos, S/N, 4450-208 Matosinhos, Portugal

${ }^{\ddagger}$ Department of Biology, Faculty of Sciences, University of Porto, Rua do Campo Alegre, 4169-007 Porto, Portugal

${ }^{\S}$ Instituto de Ciências Biomédicas de Abel Salazar (ICBAS), University of Porto, Rua de Jorge Viterbo Ferreira 228, 4050-313 Porto, Portugal

${ }^{\#}$ Centre of Health and Environmental Research-CISA, ESTSP, Polytechnic Institute of Porto, Rua Valente Perfeito 322, 4400-330 Vila Nova de Gaia, Portugal

"Institute of Biological Sciences, Center of Genomic and System Biology, Federal University of Pará (UFPA), Belém, PA 66075-110, Brazil

Supporting Information

ABSTRACT: The glycosylated and halogenated dialkylresorcinol (DAR) compounds bartolosides A-D (1-4) were recently discovered from marine cyanobacteria and represent a novel family of glycolipids, encoded by the brt biosynthetic gene cluster. Here, we report the isolation and NMR- and MS-based structure elucidation of monoglycosylated bartolosides E-K (5-11), obtained from Synechocystis salina LEGE 06099, a strain closely related to the cyanobacterium that produces the diglycosylated 2-4. In addition, a genome region containing orthologues of brt genes was identified in this cyanobacterium. Interestingly, the major bartoloside in S. salina LEGE 06099 was 1 (above $0.5 \%$ dry wt), originally isolated from the phylogenetically distant filamentous cyanobacterium Nodosilinea sp. LEGE 06102. Compounds 5-11 are analogues of 1, with different alkyl chain lengths or halogenation patterns. Their structures and the organization of the brt genes suggest that the DAR-forming ketosynthase BrtD can generate structural diversity by accepting fatty acyl-derived substrates of varying length. Compound 9 features a rare midchain gem-dichloro moiety, indicating that the putative halogenase BrtJ is able to act twice on the same midchain carbon.

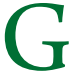
lycolipids are abundant in cyanobacteria and are present as a functionally relevant component of photosystem $\mathrm{I}^{1}$ in thylakoid and cytoplasmic membranes where they have a structural role $^{2}$ that is also related to thermotolerance, ${ }^{3}$ and in the heterocytes, creating a barrier to maintain an anoxic environment. ${ }^{4}$ Recently, we have uncovered a new class of glycolipids from marine cyanobacteria: bartolosides A-D (1-4), which are mono- or diglycosylated dialkylresorcinols (DARs) with halogenated alkyl moieties. ${ }^{5}$ The diglycosylated bartolosides 2-4, produced by the coccoid cyanobacterium Synechocystis salina LEGE 06155, feature O-linked $\alpha$-L-rhamnose and $\mathrm{C}$-linked $\beta$-xylose, while the monoglycosylated 1 produced by Nodosilinea sp. LEGE 06102 has an O-linked $\beta$-D-xylosyl moiety. The biosynthesis of the DAR skeleton of 2-4 involves first the head-to-head condensation of an $\alpha, \beta$-unsaturated fatty acylACP thioester with a $\beta$-keto-fatty acyl-ACP thioester (abundant fatty acyl derivatives in cyanobacterial cells), catalyzed by the ketosynthase BrtD. This is followed by oxidative aromatization, catalyzed by the FMN-dependent aromatase BrtC. ${ }^{5}$ Other functions encoded in the bartoloside biosynthetic gene cluster $(b r t)$ include glycosyltransferases, a putative halogenase

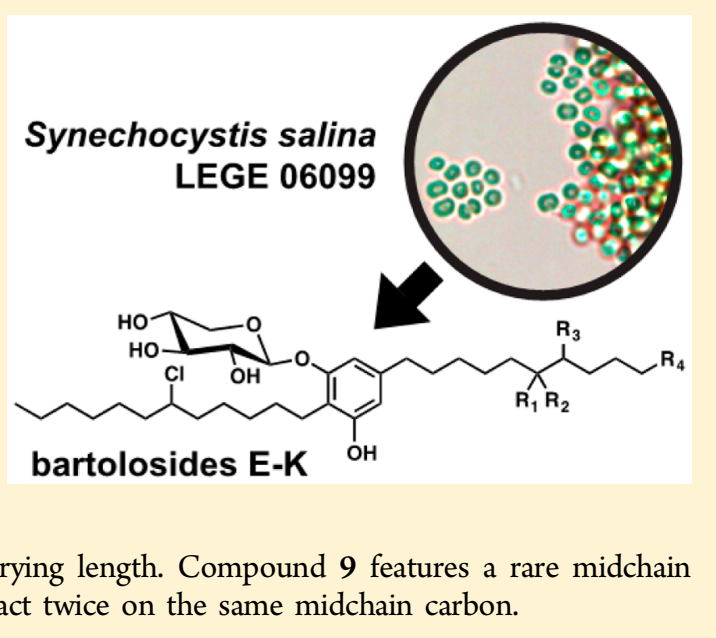

(BrtJ), and a glycolipid export cassette. ${ }^{5}$ In assays using human cancer cell lines, $\mathbf{1}$ and $\mathbf{2}$ showed low to mid micromolar cytotoxicity. ${ }^{5}$

As part of a bioassay-guided marine biodiscovery effort, we have followed a cytotoxic midpolarity fraction from one other S. salina strain (LEGE 06099) and isolated $\mathbf{1}$ as a major metabolite, together with the seven minor monoglycosylated bartolosides E-K, 5-11. We report here on the structure elucidation and biological activity of these compounds. Moreover, a putative brt gene cluster was identified in the genome of $S$. salina LEGE 06099, and the biosynthesis of mono- and diglycosylated bartolosides is discussed.

\section{RESULTS AND DISCUSSION}

Isolation and Structure Elucidation of Monoglycosylated Bartolosides from S. salina LEGE 06099. The marine cyanobacterium S. salina LEGE 06099, isolated from the intertidal

Received: April 20, 2016

Published: September 28, 2016 


\section{Chart 1}
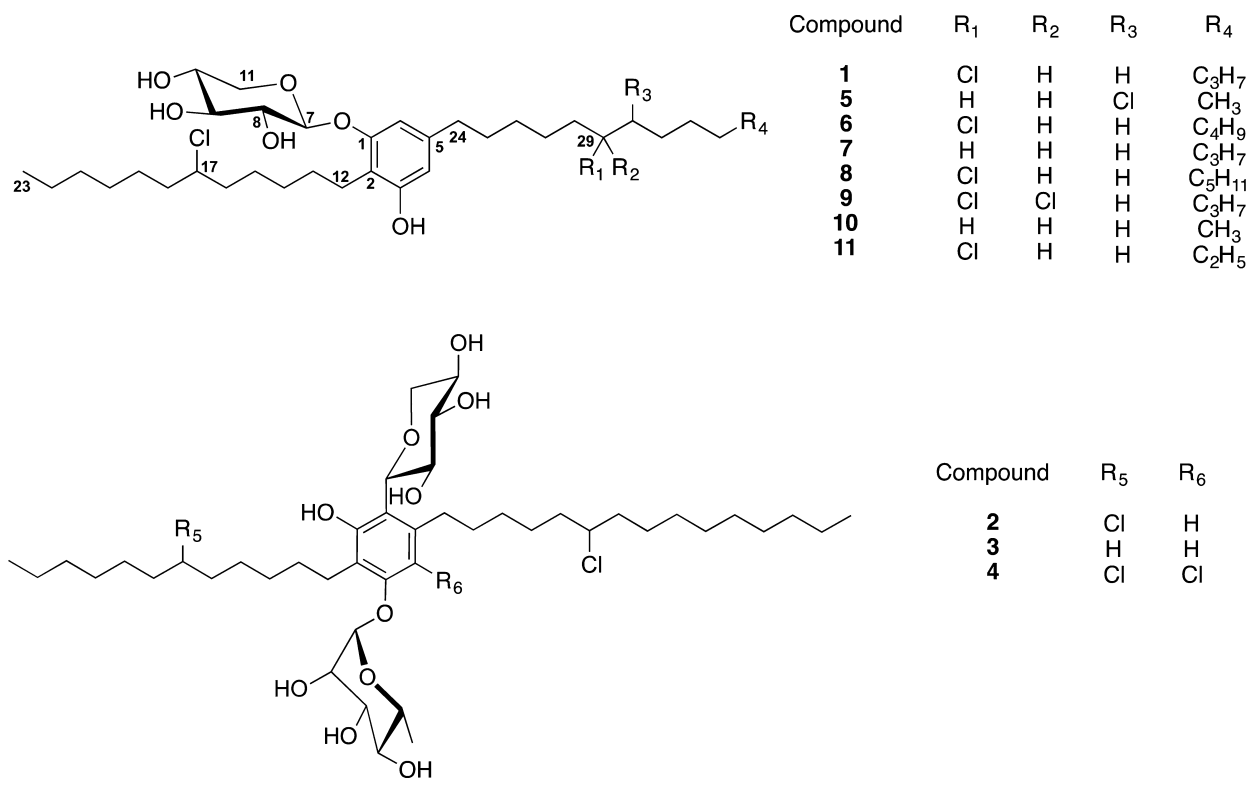

zone of a rocky beach in Northern Portugal, ${ }^{6}$ was grown in multiple $4 \mathrm{~L}$ cultures. The corresponding biomass was harvested by centrifugation and fractionated using vacuum liquid chromatography (VLC). One of the resulting fractions, eluting with EtOAc/Hex, 4:1 (v/v), showed cytotoxic activity against the MG-63, RKO, and T47D human cancer cell lines. Further fractionation by normal-phase gravity column chromatography and reversed-phase HPLC yielded pure $\mathbf{1}$ as a major metabolite, along with $\mathbf{5}$ and other minor metabolites, which showed MS patterns consistent with chlorination. The identity of $\mathbf{1}$ was established based on identical NMR, MS fragmentation, and sugar configuration data of the metabolite isolated from S. salina LEGE 06099 and of 1 isolated from Nodosilinea sp. LEGE 06102 (Figure S1, Figure S2, Table S1, Supporting Information). ${ }^{5}$ In order to obtain the minor metabolites in sufficient amounts for detailed structural characterization, S. salina LEGE 06099 was grown in a larger scale, ultimately yielding 1 (164 mg, $0.58 \%$ d.w.), as well as the minor constituents 6-11.

In our previous work with 1-4, elucidation of the planar structures, especially of the chlorinated DAR skeleton, required an integration of NMR, $\mathrm{MS}^{n}$ data, and biosynthetic information. ${ }^{5}$ In particular, HSQC-TOCSY experiments were instrumental for the assignment of the chlorinated positions, MS data informed on the alkyl chain lengths, while an understanding of which fatty acid derivatives were involved in the biosynthesis clarified the relative positions of the alkyl chains. Hence, as a general strategy to elucidate the structures of 5-11, we used such previous information on $1-4$ as a reference for comparison. All of the bartolosides herein reported contain a xylosyl moiety. Given the identical NMR data for this portion of the molecules with that of $\mathbf{1}$, we propose that this residue is $\beta$-D-xylopyranosyl for 5-11 as determined for $\mathbf{1} .^{5}$

Metabolite 5 was found to have the molecular formula $\mathrm{C}_{34} \mathrm{H}_{58} \mathrm{Cl}_{2} \mathrm{O}_{6}$ on the basis of HRESIMS data, two carbons and four protons less than compound 1 . Analysis of ${ }^{1} \mathrm{H}$ and ${ }^{13} \mathrm{C}$ APT NMR data in DMSO- $d_{6}$ quickly revealed that the sugar and aromatic regions were identical to those in 1. Furthermore, no additional methyl or methine carbon resonances were found for 5, compared to 1 . This indicated that the differences between the two compounds are two alkyl chain methylenes; to clarify where these differences were found, we resorted to HRESIMS $^{n}$ analysis of a dehalogenated, aglycone species formed in the ionization chamber, as previously observed for $\mathbf{1 - 4}$. $^{5}$ Fragmentation of this species revealed that a $\mathrm{C}_{10}$ chain was present as a substituent in position 5 of the resorcinol ring (Figure 1, Figure S3). Closer inspection of the ${ }^{13} \mathrm{C}$ NMR data for the two compounds revealed that only three methylene carbons resonating at $\sim \delta_{\mathrm{C}} 26.0-25.6$ were found in 5, compared to the four methylenes C-15, C-19, C-27, and C-31 in 1. Concomitantly, one of the methylenes vicinal to the chlorinated position in $\mathbf{5}$ was slightly more shielded $\left(\delta_{\mathrm{C}} 37.5\right)$ when compared to $\mathbf{1}$. In addition, while for 1 two $\omega$-3 carbon resonances at $\delta_{\mathrm{C}} 31.1$ and 30.7 are observed, in $\mathbf{5}$ a single $\omega-3$ carbon resonates in this region. One of the $\omega$ - 2 carbon signals is also more shielded in 5 $\left(\delta_{\mathrm{C}} 21.7 ; \delta_{\mathrm{C}} 22.0\right.$ for 1$)$. This hinted that the chlorinated methine was closer to the chain terminus in $\mathbf{5}$ when compared to $\mathbf{1}$. $\mathrm{HMBC}$ correlations connecting one of the slightly resolved methyl triplets to both an $\omega-3$ carbon resonating at $\delta_{\mathrm{C}} 28.1$ (C-32) and an $\omega-2$ carbon resonating at $\delta_{\mathrm{C}} 21.7$ (C-33) supported that chlorination in this chain would be in position $\omega-5$ (Figure 2), thereby establishing the planar structure of compound 5. Of practical importance, the structure elucidation of 5 also clarified that, in $\mathbf{1}$, the $\omega-3$ carbons in the $\mathrm{C}_{12}$ and $\mathrm{C}_{13}$ chains resonate at $\delta_{\mathrm{C}} 30.7$ and 31.1, respectively (in DMSO- $d_{6}$ ).

Metabolite 6 was found to have the molecular formula $\mathrm{C}_{37} \mathrm{H}_{64} \mathrm{Cl}_{2} \mathrm{O}_{6}$ based on HRESIMS analysis, corresponding to one additional carbon and two protons, when compared to 1 . Comparison of $1 \mathrm{D}$ and $2 \mathrm{D}$ NMR data (including HSQCTOCSY) for $\mathbf{6}$ and $\mathbf{1}$ did not reveal discernible differences, except for an additional peak in the $\delta$ 28.5-28.4 region in the spectrum of 6 , suggesting that an extra aliphatic methylene would be present in this compound. A smaller additional peak in the ${ }^{13} \mathrm{C} \mathrm{APT}$ spectrum of 6 at $\delta 31.1$ was also observed, but it lacked clear HSQC or HMBC correlations and was not considered. HRESIMS ${ }^{n}$ analysis of the in-source-isolated dechlorinated aglycone of 6 showed that the additional methylene was present in the C-5 alkyl chain substituent (Figure 1, Figure S3). The positioning of the $\mathrm{Cl}$ atom in this chain is presumed to be at a six-carbon distance from the 


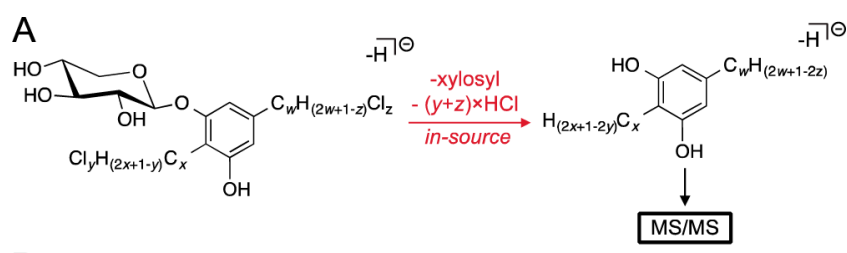

B
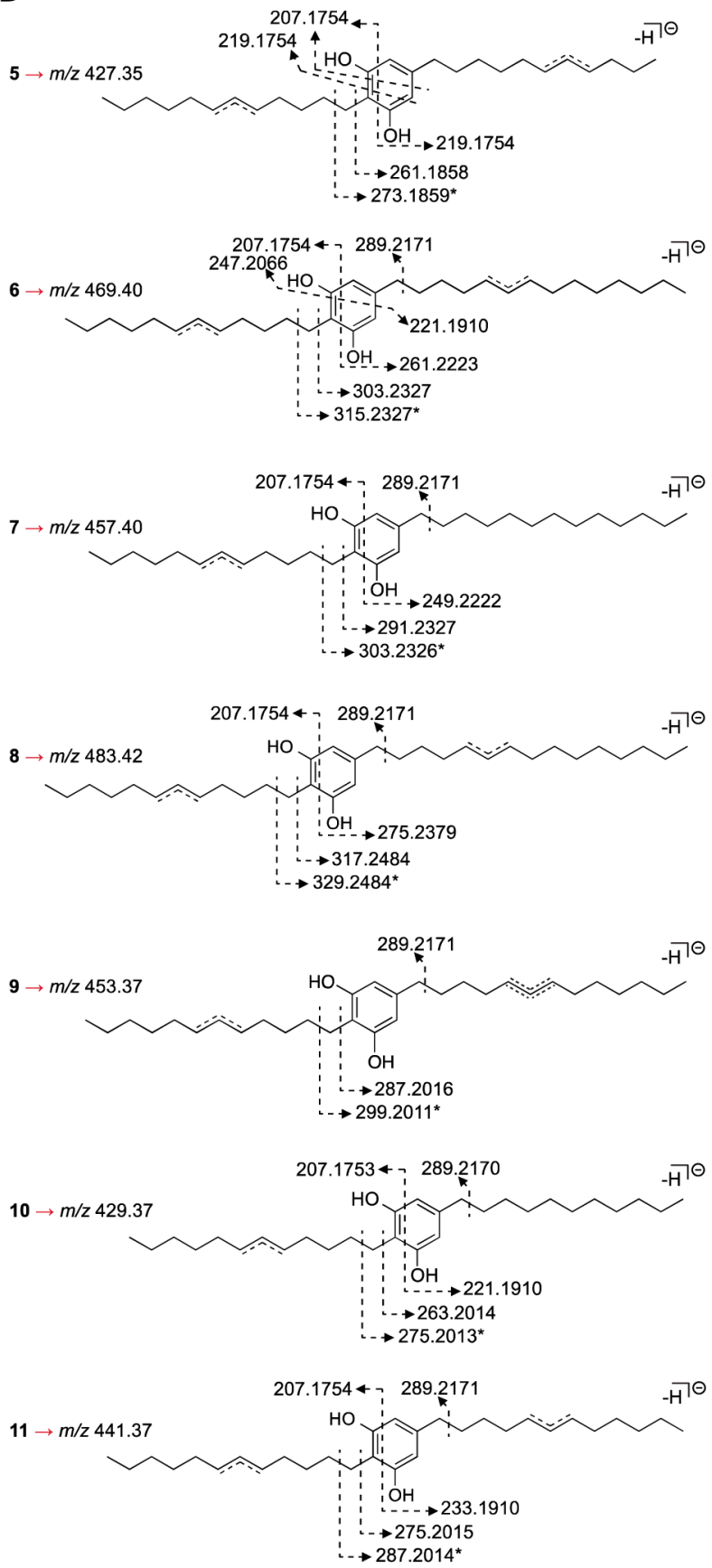

Figure 1. HRESIMS ${ }^{n}$ analysis of 5-11. (A) For each compound, an in-source-formed dechlorinated aglycone species was fragmented to provide information on the length and number of halogens of each alkyl chain. (B) Annotation of diagnostic $m / z$ values encountered in the MS/MS analysis for each species. Asterisks indicate tropolone formation following fragmentation.

resorcinol ring, due to the highly similar 1D and 2D NMR data (in particular HSQC-TOCSY) of $\mathbf{6}$ and $\mathbf{1 .}$

The HRESIMS-derived molecular formula of metabolite 7 $\left(\mathrm{C}_{36} \mathrm{H}_{63} \mathrm{ClO}_{6}\right)$ suggested that this compound could be an
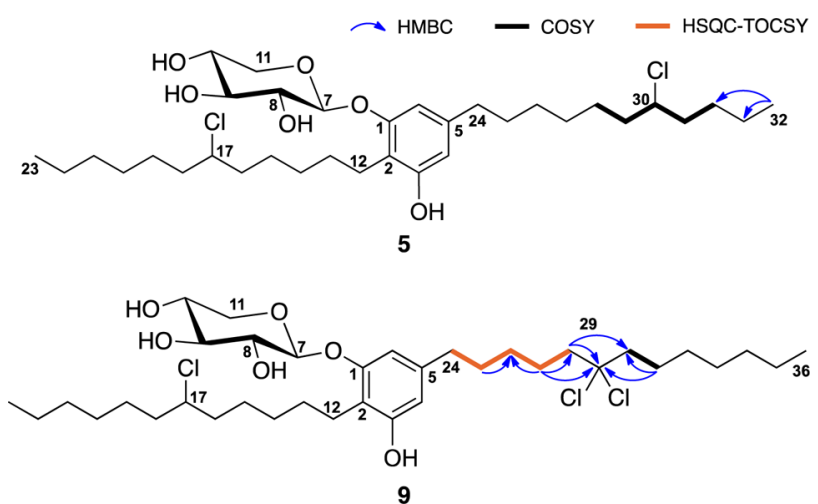

Figure 2. Key 2D NMR correlations supporting the proposed chlorine position in the C-5 alkyl substituent for metabolites 5 and 9.

analogue of $\mathbf{1}$ with a fully aliphatic alkyl chain. In fact, the ${ }^{1} \mathrm{H}$ NMR data confirmed this hypothesis, with the multiplets for the chlorinated methine and vicinal methylenes in 7 integrating for one and four protons, respectively. This was in agreement with the ${ }^{13} \mathrm{C}$ APT data, with a single carbon resonance at $\delta_{\mathrm{C}}$ 64.8 for a chlorinated methine and two carbon resonances at $\delta_{\mathrm{C}}$ 37.9-37.8 for the vicinal positions. Less shielded resonances of the methylene vicinal to the benzylic position (C-25) in the $\mathrm{C}_{13}$ chain $\left(\delta_{\mathrm{C}} 30.7\right.$ in 7 and $\delta_{\mathrm{C}} 30.6$ in $\left.\mathbf{1}\right)$ and one of the $\omega-3$ carbons $\left(\delta_{\mathrm{C}} 31.3\right.$ in 7 and $\delta_{\mathrm{C}} 31.1$ in $\left.\mathbf{1}\right)$ formed the basis for our proposal for a nonhalogenated $\mathrm{C}_{13}$ chain in 7 , which is supported by HRESIMS ${ }^{n}$ analysis (Figure 1, Figure S3).

Metabolite 8 was found to have the molecular formula $\mathrm{C}_{38} \mathrm{H}_{66} \mathrm{Cl}_{2} \mathrm{O}_{6}$ from the HRESIMS data, corresponding to two additional carbons and four protons when compared to $\mathbf{1}$. No important differences in the resonances for the aromatic and xylose residue regions between $\mathbf{8}$ and $\mathbf{1}$ were found in ${ }^{1} \mathrm{H}$ and ${ }^{13} \mathrm{C}$ APT data, nor were additional methyl or methine resonances found for 8, consistent with two extra methylenes in the alkyl chains of this compound when compared to 1 . Overall, 1D and 2D (including HSQC-TOCSY) NMR data for 8 were highly similar to those for $\mathbf{1}$, with the exception of a more complex aliphatic methylene region in the carbon spectrum of $\mathbf{8}$, as expected. A good agreement with the ${ }^{13} \mathrm{C}$ data $\left(\delta_{\mathrm{C}} 38.0-13.5\right.$ region) for $2^{5}$ led us to hypothesize that $C_{12} / C_{15}$ alkyl chains would be present in $\mathbf{8}$, which was confirmed by HRESIMS ${ }^{n}$ fragmentation analysis of the in-source-formed dechlorinated aglycone of $\mathbf{8}$ (Figure 1, Figure S3). Given the similar HSQCTOCSY data of $\mathbf{8}$ and $\mathbf{1}$ in establishing the connection from the benzylic position $\left(\mathrm{C}-/ \mathrm{H}_{2}-24\right)$ to the chlorinated methine (C-/H-29) (Figure S4), a $\omega$-10 positioning of the $\mathrm{Cl}$ atom was assigned for 8 .

Metabolite 9 was found to have the molecular formula $\mathrm{C}_{36} \mathrm{H}_{61} \mathrm{Cl}_{3} \mathrm{O}_{6}$ on the basis of HRESIMS data, consistent with an analogue of $\mathbf{1}$ bearing an additional chlorine atom. The ${ }^{1} \mathrm{H}$ and ${ }^{13} \mathrm{C}$ APT NMR data in DMSO- $d_{6}$ of 9 showed resonances for the aromatic and sugar moieties mostly identical to those of $\mathbf{1}$, although slight $(<0.03 \mathrm{ppm})$ differences were observed for the sugar and resorcinol exchangeable protons. Integration of the chlorinated methine multiplet resonating at $\delta_{\mathrm{H}} 4.01$ indicated that this corresponded to a single proton, which would be consistent with a gem-dichloro group in the molecule. A multiplet integrating for four protons at $\delta_{\mathrm{H}} 2.19\left(\mathrm{H}_{2}-28 / \mathrm{H}_{2}-30\right)$ with an HSQC correlation to two carbons at $\delta_{\mathrm{C}} 47.2-47.1$ was found to have no counterpart in the NMR data of 1 . A nonprotonated carbon $\left(\delta_{\mathrm{C}} 97.2, \mathrm{C}-29\right)$ was HMBC-correlated to the $\delta_{\mathrm{H}} 2.19$ multiplet, which in turn showed a COSY correlation to a 
multiplet at $\delta_{\mathrm{H}}$ 1.57. An HSQC experiment allowed assignment of this resonance to two methylene carbons $\left(\delta_{\mathrm{C}} 24.8,24.5\right.$, C-27/31). These protons were strongly correlated to the C-29 and C-28/30 positions. Overall, this established a midchain gem-dichloro moiety. HSQC-TOCSY revealed that the $\mathrm{H}_{2}-24$ $\left(\delta_{\mathrm{H}} 2.40\right)$ and the $\mathrm{H}_{2}-28$ protons were correlated to $\mathrm{C}-25$ $\left(\delta_{\mathrm{C}} 30.7\right)$, while the $\mathrm{H}_{2}-27\left(\delta_{\mathrm{H}} 1.57\right)$ and $\mathrm{H}_{2}-28$ protons were correlated to C-26 $\left(\delta_{\mathrm{C}} 28.2\right)$, placing the gem-dichloro group on the 5-alkyl substituent (Figure S5). HRESIMS ${ }^{n}$ analysis supported this assignment and indicated that the two alkyl chains were $\mathrm{C}_{12}$ and $\mathrm{C}_{13}$ (Figure 1, Figure S3). The exact positioning of the gem-dichlorinated position was established from the aforementioned HSQC-TOCSY data, from the COSY correlations of both the $\mathrm{H}_{2}-25\left(\delta_{\mathrm{H}} 1.50\right)$ and $\mathrm{H}_{2}-27$ protons to $\mathrm{H}_{2}$-26 $\left(\delta_{\mathrm{H}} 1.31\right)$, and from HMBC correlations between C-26 and both $\mathrm{H}_{2}-25$ and $\mathrm{H}_{2}-27$ (Figure 2, Figure S5). Selective 1D TOCSY experiments with varying mixing times supported these assignments, as the magnetization from both $\mathrm{H}_{2}-24$ and $\mathrm{H}_{2}-28$ is propagated to a $\delta_{\mathrm{H}} 1.31$-centered multiplet $\left(\mathrm{H}_{2}-26\right)$, through $\mathrm{H}_{2}-25$ and $\mathrm{H}_{2}-27$, respectively (Figure S5).

From HRESIMS analysis, metabolite $\mathbf{1 0}$ was found to have the molecular formula $\mathrm{C}_{34} \mathrm{H}_{59} \mathrm{ClO}_{6}$. Due to the low amount of compound isolated $(0.2 \mathrm{mg})$, we were unable to obtain a ${ }^{13} \mathrm{C}$ spectrum, and both the HMBC and HSQC-TOCSY data showed limited correlational information. The molecular formula indicated that 10 could be a shorter chain analogue of 1 with just one chlorination. This possibility was corroborated by the identical ${ }^{1} \mathrm{H}$ NMR data in DMSO- $d_{6}$ for the aromatic and sugar regions of 10 and 1 and by integrations of one and four protons for the signals corresponding to the chlorinated methine and vicinal methylenes, respectively, in 10. Further structural details were obtained from HRESIMS $^{n}$ analysis. Because only one chlorination is present, the dehalogenated aglycone isolated in the ionization chamber that was subject to fragmentation contained an unsaturation in only one of the chains (loss of $\mathrm{HCl}$ ) (Figure 1, Figure S3). We could therefore infer chain lengths from the MS data, as well as which of the two chains contained the unsaturation. The alkyl chain substituent at C-5 was thus found to be fully aliphatic and two carbons shorter than the corresponding alkyl chain in $\mathbf{1}$ (Figure 1, Figure S3).

Metabolite 11 was found to have the molecular formula $\mathrm{C}_{35} \mathrm{H}_{60} \mathrm{Cl}_{2} \mathrm{O}_{6}$ from HRESIMS analysis, with one $\mathrm{CH}_{2}$ formula difference compared to 1 . The ${ }^{1} \mathrm{H}$ and ${ }^{13} \mathrm{C}$ APT NMR data in DMSO- $d_{6}$ for 11 and 1 were highly similar, indicating that compound 11 should have one less alkyl chain methylene. HRESIMS ${ }^{n}$ analysis of $\mathbf{1 1}$ was used for further structural inferences. Fragmentation of the respective in-source-isolated dehalogenated aglycone species clarified that a $\mathrm{C}_{12}$ chain was a substituent at position 5 of the resorcinol ring (Figure 1, Figure S3). Given the similarity in the NMR data, the positioning of the $\mathrm{Cl}$ atom is proposed from the conserved halogenation pattern observed in the bartolosides (six-carbon distance from the aromatic ring, exception is compound $\mathbf{5}$ ).

The availability of NMR and MS data for 1-4 greatly facilitated the structure elucidation of bartolosides 5-11. Still, the precise positioning of the $\mathrm{Cl}$ atom in the C-5 alkyl substituent was only evident for compounds 5 and 9. For compounds $\mathbf{6 , 8}$, and $\mathbf{1 1}$, such positioning is in agreement with our elucidations of $\mathbf{1 - 4 .} .^{5}$ From our proposed structures, the chlorination on the C-5 substituent in $\mathbf{5}$ occurs in a different position than for all other bartolosides (seven carbons away from the resorcinol ring vs six carbons, respectively), suggesting that BrtJ is capable of acting on different positions. However, the pronounced chemical shift degeneracy for the aliphatic methylenes that are more than two carbons away from the chlorine atom moiety renders $\mathrm{Cl}$ positions in both alkyl chains difficult to differentiate from NMR (including HSQC-TOCSY) data. Therefore, structural confirmation of the proposed bartoloside structures by total synthesis is highly desirable (also for establishing the absolute configurations), since these compounds have eluded all of our crystallization attempts.

Biosynthesis of Bartolosides in S. salina LEGE 06099. While the two bartoloside-producing $S$. salina strains are phylogenetically close (Figure S6), we could not find 2-4 in an organic extract of S. salina LEGE 06099, nor could we find 1 or 5-11 in an extract of S. salina LEGE 06155 (Figure S6). To clarify how these observations translated at the genetic level and how the structural diversity observed in the compounds isolated from S. salina LEGE 06099 could be generated, we studied the biosynthesis of the bartolosides in this strain. Naturally, we envisioned that its genome would likely harbor a gene cluster with homology to the diglycosylated bartolosidegenerating brt cluster in S. salina LEGE 06155. To obtain stronger evidence for this hypothesis prior to genome sequencing, we used a degenerate PCR strategy to show that brt $C$ and $b r t D$ homologues were indeed found in the genome of S. salina LEGE 06099, by obtaining an amplicon that spanned both genes (Figure S8, 82\% identity to brtCD in S. salina LEGE 06155). Following genome sequencing and mining, we were able to identify what, in all likelihood, is the brt gene cluster in this cyanobacterium (Figure 3). As expected, the cluster is

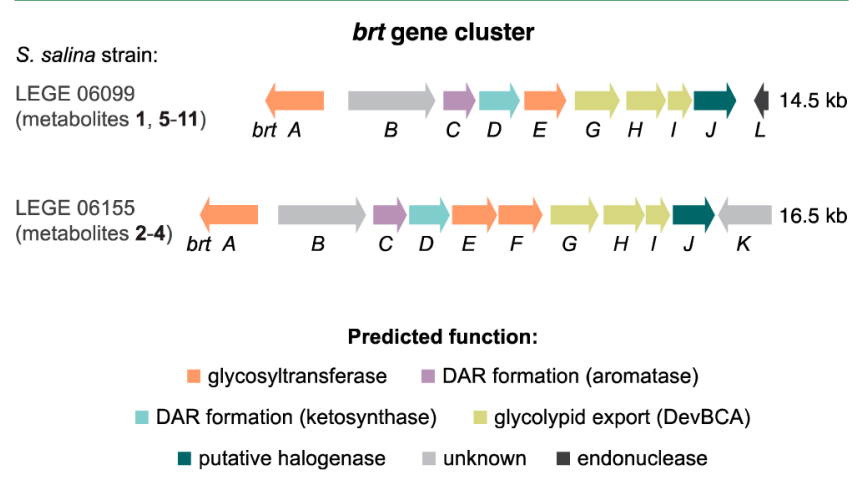

Figure 3. Overview of the brt gene clusters in S. salina strains LEGE 06099 and LEGE 06155.

highly homologous to the S. salina LEGE 06155 brt cluster (Figure 3, Table S2). However, only two glycosyltransferases are encoded in the putative brt cluster from $S$. salina LEGE 06099, as opposed to three such enzymes coded by the $S$. salina LEGE 06155 cluster. Given the strong homology between the glycosyltransferases that are shared by both clusters, it is unclear whether the two enzymes play a role in the installation of a single sugar moiety.

A putative halogenase (BrtJ) is present in the two brt clusters. Genes homologous to brt $J$ have recently been found in cyanobacterial biosynthetic gene clusters encoding halogenated natural products, ${ }^{7,8}$ and bioinformatics analyses have strongly suggested that these enzymes are a new type of dimetal halogenase. ${ }^{5,7}$ In S. salina LEGE 06099 BrtJ is therefore likely to carry out the single halogenations on unactivated carbons found in all bartolosides, but also to give rise to the gem-dichloro group in 9. This functionality is relatively rare, being found in the cyanobacterial natural products hectochlorin, ${ }^{9}$ lyngbyabellins, ${ }^{10,11}$ 
cyclophanes, ${ }^{12}$ and columbamide $\mathrm{B}^{7}$ in the myxobacterial metabolite chlorotonil $\mathrm{A},{ }^{13}$ and in a handful of marine-derived lipids. ${ }^{14}$ In hectochlorin biosynthesis halogenation is carried out by a nonheme iron $\alpha$-ketoglutarate-dependent enzyme (HctB), ${ }^{15}$ while a $\mathrm{FAD}$-dependent halogenase (CtoA) is thought to install the $\mathrm{Cl}$ atoms found in chlorotonil $\mathrm{A}^{16}$ Notably, in recent investigations of columbamide $\mathrm{B}$ and carbamidocyclophane biosyntheses, terminal gem-dichlorination has been suggested to be performed by BrtJ homologues (ColD/ColE and CabC, respectively). 7,17

Bartoloside A (1) is very abundant in S. salina LEGE 06099, making up to $0.6 \%$ of the total dry weight (d.w.). Such levels are comparable in magnitude to those of lipopolyssacharides in different cyanobacteria cells $(0.1-3 \%$, d.w. $),{ }^{18,19}$ suggesting that bartolosides may have a structural role. Bartolosides E-K (5-11) are much less abundant than bartoloside A (1) in S. salina LEGE 06099 cells. The structural diversity that the brt pathway can generate in this strain is, nevertheless, noteworthy. While some of the bartolosides are likely pathway intermediates (i.e., those with a single halogenation, 7 and 10), shorter or longer chain analogues indicate some relaxed specificity in DAR formation. Previously, we have shown that BrtD accepts evenchain fatty acyl-ACP derivatives-intermediates in fatty acid metabolism - to form the DAR core of $2-4 .{ }^{5}$ According to the proposed biosynthesis of the bartolosides, ${ }^{5}$ compounds 6 and 11 would result from the BrtD-catalyzed condensation of oddchain $\alpha, \beta$-unsaturated fatty acyl-ACP thioesters $\left(\mathrm{C}_{17}\right.$ and $\mathrm{C}_{15}$, respectively) with a 3-oxo-hexadecanoyl-ACP thioester. However, neither odd-chain fatty acids nor their $\alpha, \beta$-unsaturated fatty acyl-ACP thioesters are known to be present in cyanobacteria cells. $^{20}$ The closely related cyanobacterium Synechocystis sp. PCC 6803 is known to be able to synthesize full-length oddchain (up to $\mathrm{C}_{19}$ ) saturated and unsaturated fatty acids but only when fed with heptanoic acid. ${ }^{21}$ The fatty acid biosynthesis machinery of this cyanobacterium can thus elongate odd-chain precursors and generate also odd-chain $\alpha, \beta$-unsaturated fatty acyl-ACP thioesters. The intriguing origin of the DAR cores of $\mathbf{6}$ and 11 in S. salina LEGE 06099 will be the subject of further study.

Bioactiviy of Monoglycosylated Bartolosides. Compounds 1 and 5-11 were evaluated for their cytotoxic activity against three different human cancer cell lines, namely, MG-63 (bone osteosarcoma), RKO (colon carcinoma), and T-47D (mammary gland ductal carcinoma). The bartolosides were considered inactive $\left(\mathrm{IC}_{50}>10 \mu \mathrm{M}\right)$ against all tested cell lines. For compounds $\mathbf{1}$ and $\mathbf{5}$ we were able to determine $\mathrm{IC}_{50}$ values of 22 and $39 \mu \mathrm{M}$ against MG-63 cells, 40 and $40 \mu \mathrm{M}$ against RKO cells, and 23 and $22 \mu \mathrm{M}$ against T-47D cells, respectively, and exposure to 9 revealed an $\mathrm{IC}_{50}$ of $59.8 \mu \mathrm{M}$ in the assay with the T-47D cell line.

\section{CONCLUSION}

Our report on the structures of seven new bartolosides provides a framework for the future structure elucidation of related compounds. The structures and the biosynthesis of the monoglycosylated bartolosides in S. salina LEGE 06099 bring up important questions regarding the function of the encoded glycosyltransferases and the potential involvement of odd-chain fatty acyl derivatives. Notably, the likely role of the putative halogenase BrtJ in carrying out a selective midchain dichlorination adds to the different types of halogenation that have been hypothesized for this still uncharacterized group of enzymes. Apparently, the bartolosides do not have strong bioactive properties; however, their high abundance inside the cells suggests that these may have a fundamental biological role, which we intend to further investigate.

\section{EXPERIMENTAL SECTION}

General Experimental Procedures. Optical rotations were measured on a Jasco P-2000 polarimeter (average of 10 measurements, $589 \mathrm{~nm}$ ) using a $1 \mathrm{~mL}$ sample cell, with the exception of the optical rotation of 1 in $\mathrm{MeCN}$, which was measured on an ADP410 polarimeter (Bellingham + Stanley Ltd.), also at $589 \mathrm{~nm}$. UV-vis spectra were acquired on a Synergi HT microplate reader (BioTek) equipped with a Take 3 plate and a quartz cuvette. IR spectra were collected on a Jasco FT/IR 460 Plus spectrometer. NMR data were acquired in the indicated solvents in either a $400 \mathrm{MHz}$ Bruker Avance III or a $600 \mathrm{MHz}$ Bruker Avance III equipped with a $5 \mathrm{~mm}$ cryoprobe. Selective 1D TOCSY experiments were carried out with a magnetic susceptibility-matched (DMSO) NMR tube (Shigemi). Acquisition of NMR data for 1 isolated from Nodosiliena sp. LEGE 06102 was detailed previously. ${ }^{5}$ HRESIMS ${ }^{n}$ data of pure compounds were acquired on an LTQ Orbitrap XL spectrometer, controlled by LTQ Tune Plus 2.5.5 and Xcalibur 2.1 (Thermo Scientific). The capillary voltage of the ESI was set to $-3000 \mathrm{~V}$. The capillary temperature was $300{ }^{\circ} \mathrm{C}$. The sheath gas flow rate (nitrogen) was set to 5 (arbitrary unit as provided by the software settings). The capillary voltage was $-48 \mathrm{~V}$ and the tube lens voltage -247.79 V. Samples were injected at a concentration of $50 \mu \mathrm{g} / \mathrm{mL}$. Selected ions were fragmented using collision-induced dissociation (CID) with a normalized collision energy of $40 \%$. For the HRESIMS ${ }^{2}$ chiral recognition analysis used to determine xylose configuration, the same instrument was used, but with an ESI capillary voltage of $3100 \mathrm{~V}$, capillary temperature of $275^{\circ} \mathrm{C}$, capillary voltage of $42 \mathrm{~V}$, and tube lens voltage of $85 \mathrm{~V}$. Selected ions were fragmented using CID with a normalized collision energy of $30 \%$. The maximum injection time for the $\mathrm{MS}^{n}$ analysis and isolation width were found to be optimal for this analysis at $50 \mathrm{~ms}$ and $4.0 \mathrm{~m} / z$, respectively.

LC-HRESIMS profiles of extracts from S. salina LEGE 06099 and S. salina LEGE 06155 were acquired in an Accela HPLC coupled to an Accela PDA detector, Accela autosampler, and Accela 600 pump and to an LTQ Orbitrap XL spectrometer that was operated in negative ion mode under the conditions described above for HRESIMS ${ }^{n}$ analysis. Analytical and semipreparative-scale HPLC purifications were carried out using a Waters 1525 binary pump, coupled to a Waters 2487 detector (monitored wavelengths: 230 and $275 \mathrm{~nm}$ ).

All solvents used were MS-grade or HPLC-gradient grade for MS-based experiments, HPLC gradient for HPLC analysis/purification, and ACS grade for extraction, VLC, flash, and gravity column chromatographies. NMR solvents were acquired from either Sigma-Aldrich or BDH Prolabo (VWR).

Cyanobacterial Strains. Synechocystis salina LEGE 06099 and $S$. salina LEGE 06155 were obtained from the LEGE Culture Collection and grown at $25{ }^{\circ} \mathrm{C}$, under a 14:10 h light $(\sim 30 \mu \mathrm{mol}$ photons $\left.\mathrm{m}^{-2} \mathrm{~s}^{-1}\right) /$ dark regimen, in $\mathrm{Z} 8$ medium ${ }^{22}$ supplemented with $25 \mathrm{~g} \mathrm{~L}^{-1} \mathrm{NaCl}$ and $20 \mu \mathrm{g} \mathrm{L}^{-1}$ vitamin $\mathrm{B}_{12}$.

Extraction and Isolation. Multiple cultures of $S$. salina LEGE 06099 were carried out in $6 \mathrm{~L}$ glass flasks with $4 \mathrm{~L}$ of medium. Biomass from a total of $120 \mathrm{~L}$ of culture was centrifuged $(4500 \mathrm{~g}, 10 \mathrm{~min})$, rinsed with deionized $\mathrm{H}_{2} \mathrm{O}$, harvested by another round of centrifugation, and freeze-dried to yield $15.3 \mathrm{~g}$ (d.w.). The biomass was extracted by repeated percolation with a warm mixture of $\mathrm{CH}_{2} \mathrm{Cl}_{2} / \mathrm{MeOH}$ $(2: 1, \mathrm{v} / \mathrm{v})$. The resulting extract $(2.6 \mathrm{~g})$ was fractionated by normalphase (Si gel 60, 0.015-0.040 mm, Merck KGaA) VLC using a gradient of increasing polarity from hexanes to EtOAc to $\mathrm{MeOH}$, which yielded nine fractions (A-I). Fraction F, eluting with 4:1 EtOAc/MeOH (v/v), caused a marked reduction $(>80 \%)$ in the viability of human cancer cell lines RKO, MG-63, and T-47D, when tested at $100 \mu \mathrm{g} / \mathrm{mL}$ (Cytotoxicity Assays subsection), and was further fractionated by gravity column chromatography using Si gel $60(0.040-0.063 \mathrm{~mm}$, Merck $\mathrm{KGaA})$ as stationary phase and a gradient of increasing polarity from 3:7 EtOAc/Hex (v/v) to EtOAc to 1:4 MeOH/EtOAc (v/v). The resulting subfractions were pooled according to their TLC profiles, and two 
adjacent subfractions (F5 and F6), eluting with 2:3 EtOAc/Hex (v/v), contained the previously observed activity toward human cancer cell lines. Following semipreparative HPLC separations of each of the subfractions F5 (isocratic, $87 \% \mathrm{MeCN}(\mathrm{aq}), 3 \mathrm{~mL} / \mathrm{min}$, on a Synergi Fusion-RP column, $250 \times 10 \mathrm{~mm}, 10 \mu \mathrm{m})$ and $\mathrm{F} 6(85 \% \mathrm{MeCN}(\mathrm{aq})$ to $100 \% \mathrm{MeCN}$ linear gradient over $25 \mathrm{~min}, 3 \mathrm{~mL} / \mathrm{min}$, on a Synergi Fusion-RP column, $250 \times 10 \mathrm{~mm}, 10 \mu \mathrm{m}$, Phenomenex), compound 1 was isolated as the main component in both subfractions $(30.4 \mathrm{mg}$, $t_{\mathrm{R}}=28.5 \mathrm{~min}$ and $12.8 \mathrm{mg}, t_{\mathrm{R}}=21.3 \mathrm{~min}$, respectively, total $43.2 \mathrm{mg}$, $0.28 \%$ d.w.). The aforementioned HPLC separation of subfraction F6 also yielded a fraction $\left(t_{\mathrm{R}}=15.0-16.7 \mathrm{~min}\right)$ with ${ }^{1} \mathrm{H}$ NMR signals that could correspond to a bartoloside-like compound and was subjected to analytical-scale HPLC separation (isocratic, $70 \% \mathrm{MeCN}(\mathrm{aq}), 1 \mathrm{~mL} / \mathrm{min}$, on a Synergi Fusion-RP column, $250 \times 4.6 \mathrm{~mm}, 4 \mu \mathrm{m}$, Phenomenex) to yield pure $5\left(0.5 \mathrm{mg}, 0.003 \%\right.$ d.w., $\left.t_{\mathrm{R}}=39.6 \mathrm{~min}\right)$.

To obtain sufficient amounts of the minor halogenated compounds present in the cells of S. salina LEGE 06099 for structure elucidation, large-scale culturing of the cyanobacterium was carried out to yield $28.3 \mathrm{~g}$ of biomass (d.w.), after harvesting by centrifugation and freezedrying. Following organic extraction and VLC (performed as above), fraction $\mathrm{F}$ contained ${ }^{1} \mathrm{H}$ NMR signals consistent with bartolosidelike metabolites and was further fractionated using gravity column chromatography as detailed above. Subfractions F3, F4, and F5 contained bartoloside-like ${ }^{1} \mathrm{H}$ NMR signals. Subfraction F3 was then fractionated using semipreparative HPLC using a Synergi Hydro-RP column $(10 \mu \mathrm{m}, 250 \times 10 \mathrm{~mm}$, Phenomenex). The elution was carried out at $3 \mathrm{~mL} / \mathrm{min}$ and consisted initially of isocratic conditions $(87 \%$ $\mathrm{MeCN}$, aqueous) for $30 \mathrm{~min}$, followed by a $5 \mathrm{~min}$ gradient to reach $100 \% \mathrm{MeCN}$, which was held for an additional $25 \mathrm{~min}$. This afforded pure $1\left(47.5 \mathrm{mg}, 0.17 \%\right.$ d.w., $\left.t_{\mathrm{R}}=26.5 \mathrm{~min}\right), 6(2.6 \mathrm{mg}, 0.009 \%$ d.w., $\left.t_{\mathrm{R}}=34.2 \mathrm{~min}\right), 7\left(3.1 \mathrm{mg}, 0.011 \%\right.$ d.w., $\left.t_{\mathrm{R}}=38.0 \mathrm{~min}\right)$, and $8(4.4 \mathrm{mg}$, $0.016 \%$ d.w., $\left.t_{\mathrm{R}}=38.5 \mathrm{~min}\right)$, as well as subfraction $\mathrm{F} 33(0.7 \mathrm{mg}$, $t_{\mathrm{R}}=24.0 \mathrm{~min}$ ), which contained a bartoloside-like metabolite (from ${ }^{1} \mathrm{H}$ NMR analysis) among other components. The latter HPLC subfraction was subjected to analytical-scale HPLC purification under isocratic conditions ( $90 \%$ aqueous $\mathrm{MeCN}, 1 \mathrm{~mL} / \mathrm{min}$ ) using a Synergi Hydro-RP column $(4 \mu \mathrm{m}, 250 \times 4.6 \mathrm{~mm}$, Phenomenex $)$ to afford 10 $\left(0.2 \mathrm{mg}, 0.0007 \%\right.$ d.w., $t_{\mathrm{R}}=7.5 \mathrm{~min}$ ). Subfractions F4 and F5 (from gravity column chromatography) were pooled based on an identical ${ }^{1} \mathrm{H}$ NMR profile and were also further processed by semipreparative HPLC using a Synergi Fusion-RP column $(10 \mu \mathrm{m}, 250 \times 10 \mathrm{~mm}$, Phenomenex) and an elution program with a flow of $3 \mathrm{~mL} / \mathrm{min}$ consisting of isocratic conditions for $30 \mathrm{~min}$ with $86 \% \mathrm{MeCN}(\mathrm{aq})$, followed by a $5 \mathrm{~min}$ gradient to $100 \% \mathrm{MeCN}$, and these conditions were held for an additional $25 \mathrm{~min}$. The procedure yielded pure 1 $\left(116.5 \mathrm{mg}, 0.41 \%\right.$ d.w., $\left.t_{\mathrm{R}}=19.5 \mathrm{~min}\right), 11$ (5.4 mg, 0.019\% d.w., $t_{\mathrm{R}}=$ $40.5 \mathrm{~min})$, and a fraction that also contained bartoloside-like ${ }^{1} \mathrm{H}$ NMR signals, but that required further purification. This was carried out under analytical-scale, isocratic HPLC conditions (77\% aqueous $\mathrm{MeCN}, 1.2 \mathrm{~mL} / \mathrm{min})$ using a Synergi Fusion-RP column $(4 \mu \mathrm{m}$, $250 \times 10 \mathrm{~mm}$, Phenomenex $)$ to afford $9(0.48 \mathrm{mg}, 0.0017 \%$ d.w., $\left.t_{\mathrm{R}}=35.0 \mathrm{~min}\right)$.

Bartoloside A (1): white, glassy solid; $[\alpha]_{\mathrm{D}}^{20}-31.2($ c $0.32, \mathrm{MeCN})$, $[\alpha]_{\mathrm{D}}^{24}-25.4\left(c 0.17, \mathrm{CHCl}_{3}\right)$; IR (thin film) $\nu_{\max } 3328,2921,2852$, $1579,1427,1039 \mathrm{~cm}^{-1}$; ${ }^{1} \mathrm{H}$ and ${ }^{13} \mathrm{C}$ NMR data, Table S1; HRESIMS $m / z 659.3838[\mathrm{M}-\mathrm{H}]^{-}$(calcd for $\mathrm{C}_{36} \mathrm{H}_{61} \mathrm{Cl}_{2} \mathrm{O}_{6}, 659.3851$ ).

Bartoloside $E$ (5): white, glassy solid; $[\alpha]_{\mathrm{D}}^{20}+54\left(c 0.008, \mathrm{CHCl}_{3}\right)$; IR (thin film) $\nu_{\max } 3413,2919,2850,1585 \mathrm{~cm}^{-1}$; UV (MeOH) $\lambda_{\max }$ $(\log \varepsilon) 209$ (4.2), 228 (3.9), 259 (3.3), $299(2.9) \mathrm{nm} ;{ }^{1} \mathrm{H}$ and ${ }^{13} \mathrm{C}$ NMR, HMBC, and COSY data, Table 1; HRESIMS $\mathrm{m} / \mathrm{z} 631.3517$ $[\mathrm{M}-\mathrm{H}]^{-}$(calcd for $\mathrm{C}_{34} \mathrm{H}_{57} \mathrm{Cl}_{2} \mathrm{O}_{6}, 631.3538$ ).

Bartoloside $F$ (6): white, glassy solid; $[\alpha]_{\mathrm{D}}^{19}$ (not determined, measured value $>3000$ ); IR (thin film) $\nu_{\max } 3388,2923,2852,1575$, 1434, $1043 \mathrm{~cm}^{-1}$; UV (MeOH) $\lambda_{\max }(\log \varepsilon) 205$ (3.3), 229 (3.6), 271 (3.0) $\mathrm{nm} ;{ }^{1} \mathrm{H}$ and ${ }^{13} \mathrm{C}$ NMR data, Table 2; HRESIMS $m / z 673.4002$ $[\mathrm{M}-\mathrm{H}]^{-}$(calcd for $\mathrm{C}_{37} \mathrm{H}_{63} \mathrm{Cl}_{2} \mathrm{O}_{6}, 673.4007$ ).

Bartoloside $G$ (7): white, glassy solid; $[\alpha]_{\mathrm{D}}^{21}-2.1\left(\right.$ c $\left.0.12, \mathrm{CHCl}_{3}\right)$; IR (thin film) $\nu_{\max } 3403,2921,2850,1457,1041 \mathrm{~cm}^{-1}$; UV (MeOH) $\lambda_{\max }(\log \varepsilon) 205$ (3.3), $229(3.6), 272(3.0) \mathrm{nm} ;{ }^{1} \mathrm{H},{ }^{13} \mathrm{C}$ NMR data,
Table 2; HRESIMS $m / z 625.4239[\mathrm{M}-\mathrm{H}]^{-}$(calcd for $\mathrm{C}_{36} \mathrm{H}_{62} \mathrm{ClO}_{6}$, 625.4240).

Bartoloside $H$ (8): white, glassy solid; $[\alpha]_{\mathrm{D}}^{21}+0.9\left(\right.$ c $\left.0.22, \mathrm{CHCl}_{3}\right)$; IR (thin film) $\nu_{\max } 3392,2923,2852,1428,1041 \mathrm{~cm}^{-1}$; UV (MeOH) $\lambda_{\max }(\log \varepsilon) 205(3.3), 229(3.6), 271(3.1) \mathrm{nm} ;{ }^{1} \mathrm{H}$ and ${ }^{13} \mathrm{C}$ NMR data, Table 2; HRESIMS $\mathrm{m} / z 687.4160[\mathrm{M}-\mathrm{H}]^{-}$(calcd for $\left.\mathrm{C}_{38} \mathrm{H}_{65} \mathrm{Cl}_{2} \mathrm{O}_{6}, 687.4164\right)$.

Bartoloside I (9): white, glassy solid; $[\alpha]_{\mathrm{D}}^{21}+22.6\left(c 0.016, \mathrm{CHCl}_{3}\right)$; IR (thin film) $\nu_{\max } 3419,2923,2854,1049 \mathrm{~cm}^{-1}$; UV (MeOH) $\lambda_{\max }$ $(\log \varepsilon) 202$ (3.8), 207 (4.1), $272(3.0) \mathrm{nm} ;{ }^{1} \mathrm{H}$ and ${ }^{13} \mathrm{C}$ NMR, HMBC, and COSY data, Table 1 ; HRESIMS $m / z 693.3454[\mathrm{M}-\mathrm{H}]^{-}($calcd for $\left.\mathrm{C}_{36} \mathrm{H}_{60} \mathrm{Cl}_{3} \mathrm{O}_{6}, 693.3461\right)$.

Bartoloside J (10): white, glassy solid; $[\alpha]_{\mathrm{D}}^{21}$ (not determined, measured value $>300$ ); IR (thin film) $\nu_{\max } 3397,2971,2921,2859$, $1054 \mathrm{~cm}^{-1}$; UV $(\mathrm{MeOH}) \lambda_{\max } 203,226,272 \mathrm{~nm}$ (molar absorptivity not determined, very low concentration); ${ }^{1} \mathrm{H}$ and ${ }^{13} \mathrm{C}$ NMR data, Table 2; HRESIMS $m / z 597.3923[\mathrm{M}-\mathrm{H}]^{-}\left(\right.$calcd for $\mathrm{C}_{34} \mathrm{H}_{58} \mathrm{ClO}_{6}$, 597.3927).

Bartoloside K (11): white, glassy solid; $[\alpha]_{\mathrm{D}}^{21}-9.7\left(c\right.$ 0.24, $\left.\mathrm{CHCl}_{3}\right)$; IR (thin film) $\nu_{\max } 3370,2923,2852,1585,1455,1428,1041 \mathrm{~cm}^{-1}$; $\mathrm{UV}(\mathrm{MeOH}) \lambda_{\max }(\log \varepsilon) 204(2.8), 229(3.1), 272(2.6) ;{ }^{1} \mathrm{H}$ and ${ }^{13} \mathrm{C}$ NMR data, Table 2; HRESIMS $\mathrm{m} / z 645.3686[\mathrm{M}-\mathrm{H}]^{-}$(calcd for $\left.\mathrm{C}_{35} \mathrm{H}_{59} \mathrm{Cl}_{2} \mathrm{O}_{6}, 645.3694\right)$.

Sugar Configuration Analysis. An MS chiral recognition approach was used to determine the configuration of the xylose moiety and establish the identity of compound $\mathbf{1}$ isolated from S. salina LEGE 06099. The protocol by Augusti and co-workers ${ }^{23}$ was slightly modified, as xylose had not been used in that study. Briefly, 1:1 (v/v) aqueous $\mathrm{MeOH}$ solutions containing $2 \mathrm{mM}$ D- or L-xylose (SigmaAldrich), $2 \mathrm{mM} \mathrm{N}$-Ac-L-Tyr (Sigma-Aldrich), and $1 \mathrm{mM} \mathrm{CuSO}_{4}$ were injected onto the mass spectrometer, and the trimeric ions $[\mathrm{Cu}(\mathrm{N}$ Ac-L-Tyr $\left.)_{2}(\mathrm{D} / \mathrm{L}-\mathrm{Xyl})\right]^{+}$were fragmented by CID. The average relative abundance of the dimeric ions $\left[\mathrm{Cu}(\mathrm{N}-\mathrm{Ac}-\mathrm{L}-\mathrm{Tyr})_{2}\right]^{+}$and $[\mathrm{Cu}(\mathrm{N}-\mathrm{Ac}-\mathrm{L}-$ $\mathrm{Tyr})(\mathrm{D} / \mathrm{L}-\mathrm{Xyl})]^{+}$observed in the HRESIMS ${ }^{2}$ spectra was determined for 30 scans, so as to calculate the average relative abundance ratios $R_{\mathrm{D}}$ and $R_{\mathrm{L}}$ for each sugar $\left(R_{\mathrm{D} / \mathrm{L}}=\left[\mathrm{Cu}(\mathrm{N}-\mathrm{Ac}-\mathrm{L}-\mathrm{Tyr})_{2}\right]^{+} /[\mathrm{Cu}(\mathrm{N}-\mathrm{Ac}-\mathrm{L}-\right.$ $\left.\mathrm{Tyr})(\mathrm{D} / \mathrm{L}-\mathrm{Xyl})]^{+}\right)$. A chiral discrimination factor of $1.18\left(R_{\mathrm{p}} / R_{\mathrm{L}}\right)$ was obtained. Finally, the $R$ value obtained from a solution containing the hydrolyzed sugar from 1 instead of the xylose standard was also determined and compared to $R_{\mathrm{D}}$ and $R_{\mathrm{L}}$. Hydrolysis of $1(1.3 \mathrm{mg})$ had been carried out in $2 \mathrm{M} \mathrm{HCl}(1 \mathrm{~mL})$ at $100{ }^{\circ} \mathrm{C}$ for $1 \mathrm{~h}$. After solvent removal in vacuo, the residue was resuspended in $1.5 \mathrm{~mL}$ of deionized $\mathrm{H}_{2} \mathrm{O}$ and washed twice with $1 \mathrm{~mL}$ of $\mathrm{Et}_{2} \mathrm{O}$. The aqueous layer was dried in vacuo and resuspended in $100 \mu \mathrm{L}$ of deionized $\mathrm{H}_{2} \mathrm{O}(\sim 20 \mathrm{mM}$ xylose, assuming complete hydrolysis).

Primer Design and brtCD Amplification and Sequencing. Degenerate primers brtC-385F ( $5^{\prime}$ AATATGTGGCAYTCWGCYTCRG $3^{\prime}$ ) and brtD-596R (5' GCATCRGAAAGCATCCA $3^{\prime}$ ) were designed to amplify a $\sim 1200 \mathrm{bp}$ fragment of the $b r t C D$ region (as expected from the brt gene cluster of $S$. salina LEGE 06155), by annealing to conserved regions in $b r t C$ and $b r t D$ homologues, respectively (Figure S8). To this end, alignments of BrtC and BrtD protein sequences that were available in GenBank were carried out using the Geneious alignment tool in the Geneious software package (Biomatters Limited), and strongly conserved regions identified in the alignments; the corresponding nucleotide sequences were then used to design the degenerate primers (Figure S8). Total genomic DNA (gDNA) from fresh pellets of $S$. salina LEGE 06099 or LEGE 06155 (positive control for PCR) was isolated using a commercial kit (Gram-negative bacteria protocol, PureLink genomic DNA mini kit, Invitrogen). PCR amplification using the isolated gDNAs as templates was then carried out with the Platinum Taq high-fidelity DNA polymerase (Invitrogen) and the two degenerate primers. A thermal cycling protocol composed of initial denaturing at $98{ }^{\circ} \mathrm{C}(30 \mathrm{~s})$, followed by 35 cycles of denaturing $\left(98{ }^{\circ} \mathrm{C}, 10 \mathrm{~s}\right)$, annealing $\left(55^{\circ} \mathrm{C}, 30 \mathrm{~s}\right)$, and elongation $\left(72{ }^{\circ} \mathrm{C}, 60 \mathrm{~s}\right)$ steps and a final elongation step $\left(72{ }^{\circ} \mathrm{C}\right.$, $7 \mathrm{~min}$ ) was used. A fragment of the expected size was visualized in an agarose gel for both strains (Figure S8). The band corresponding to the amplicon from $S$. salina LEGE 06099 was excised and purified using a cleanup kit (Nucleospin Gel and PCR-Clean Up, Machery-Nagel). 
Table 1. NMR Spectroscopic Data $\left({ }^{1} \mathrm{H} 600 \mathrm{MHz},{ }^{13} \mathrm{C} 150 \mathrm{MHz}, \mathrm{DMSO}-d_{6}\right)$ for Compounds 5 and 9

\begin{tabular}{|c|c|c|c|c|c|c|c|c|c|}
\hline \multirow[b]{2}{*}{ position } & \multicolumn{4}{|c|}{ bartoloside E (5) } & \multicolumn{5}{|c|}{ bartoloside I (9) } \\
\hline & $\delta_{\mathrm{C}}$, type & $\delta_{\mathrm{H}}(J$ in $\mathrm{Hz})$ & $\mathrm{HMBC}^{a}$ & COSY & no. & $\delta_{\mathrm{C}}$, type & $\delta_{\mathrm{H}}(J$ in $\mathrm{Hz})$ & $\mathrm{HMBC}^{a}$ & COSY \\
\hline 1 & 156.2, C & & & & 1 & 156.2, C & & & \\
\hline 2 & $115.8, \mathrm{C}$ & & & & 2 & $115.8, \mathrm{C}$ & & & \\
\hline 3 & 155.6, C & & & & 3 & 155.6, C & & & \\
\hline $3-\mathrm{OH}$ & & $8.99, \mathrm{~s}$ & 2,3 & & $3-\mathrm{OH}$ & & $9.00, \mathrm{~d}(2.7)$ & 2,3 & \\
\hline 4 & 109.0, $\mathrm{CH}$ & $6.29, \mathrm{~s}$ & $2,3,6,24$ & 24 & 4 & 109.0, CH & $6.29, \mathrm{~s}$ & $2,3,6,24$ & \\
\hline 5 & $140.3, \mathrm{C}$ & & & & 5 & $140.3, \mathrm{C}$ & & & \\
\hline 6 & 106.2, $\mathrm{CH}$ & $6.31, \mathrm{~s}$ & $1,2,4,24$ & 24 & 6 & 106.1, $\mathrm{CH}$ & $6.31, \mathrm{~s}$ & $1,2,4,24$ & \\
\hline 7 & $101.8, \mathrm{CH}$ & $4.70, \mathrm{~d}(7.2)$ & 1 & 8 & 7 & $101.8, \mathrm{CH}$ & $4.70, \mathrm{~d}(6.9)$ & & 8 \\
\hline 8 & 73.3, $\mathrm{CH}$ & $3.20, \mathrm{~m}$ & 7,9 & $7,8-\mathrm{OH}$ & 8 & 73.3, $\mathrm{CH}$ & $3.21, \mathrm{~m}$ & 7 & $7,8-\mathrm{OH}$ \\
\hline $8-\mathrm{OH}$ & & $5.16, \mathrm{~d}(5.1)$ & 8,9 & 8 & $8-\mathrm{OH}$ & & $5.17, \mathrm{t}(5.2)$ & 8,9 & 8 \\
\hline 9 & 76.6, $\mathrm{CH}$ & $3.20, \mathrm{~m}$ & 8 & 9-OH & 9 & 76.6, $\mathrm{CH}$ & $3.20, \mathrm{~m}$ & & 9-OH \\
\hline 9-OH & & $5.04, \mathrm{~d}(3.3)$ & & 9 & $9-\mathrm{OH}$ & & $5.04, \mathrm{~d}(2.8)$ & 10 & 9 \\
\hline 10 & $69.4, \mathrm{CH}$ & $3.35, \mathrm{~m}$ & 8 & $\begin{array}{l}10-\mathrm{OH}, 11 \mathrm{a} \\
11 \mathrm{~b}\end{array}$ & 10 & $69.4, \mathrm{CH}$ & $3.35, \mathrm{~m}$ & & $\begin{array}{l}\text { 10-OH, 11a, } \\
11 \mathrm{~b}\end{array}$ \\
\hline $10-\mathrm{OH}$ & & $5.01, \mathrm{~d}(4.9)$ & 9,11 & 10 & $10-\mathrm{OH}$ & & $5.01, \mathrm{~d}(4.9)$ & 11 & 10 \\
\hline $11 \mathrm{a}$ & 65.6, $\mathrm{CH}_{2}$ & $\begin{array}{l}\text { 3.71, dd (11.2, } \\
5.3)\end{array}$ & $7,9,10$ & $10,11 b$ & $11 \mathrm{a}$ & 65.6, $\mathrm{CH}_{2}$ & $\begin{array}{l}\text { 3.72, dd (11.3, } \\
5.3)\end{array}$ & 7 & $10,11 b$ \\
\hline $11 b$ & & $3.16, \mathrm{dd}(\sim 11.1)$ & 7 & $10,11 \mathrm{a}$ & $11 \mathrm{~b}$ & & 3.16, dd $(\sim 10.6)$ & 9 & $10,11 \mathrm{a}$ \\
\hline $12 \mathrm{a}$ & 22.5, $\mathrm{CH}_{2}$ & $2.54, \mathrm{~m}$ & $1,2,3,13$ & $12 b, 13$ & $12 \mathrm{a}$ & 22.5, $\mathrm{CH}_{2}$ & $2.54, \mathrm{~m}$ & 2 & $12 b, 13$ \\
\hline $12 b$ & & $2.46, \mathrm{~m}$ & $1,2,3,13$ & $12 \mathrm{a}, 13$ & $12 \mathrm{~b}$ & & $2.47, \mathrm{~m}$ & 2 & $12 \mathrm{a}, 13$ \\
\hline 13 & 28.8, $\mathrm{CH}_{2}$ & $1.40, \mathrm{~m}$ & & $12 \mathrm{a}, 12 \mathrm{~b}$ & 13 & 28.7, $\mathrm{CH}_{2}$ & $1.40, \mathrm{~m}$ & & $12 a, 12 b$ \\
\hline 14 & $29.0-28.5, \mathrm{CH}_{2}$ & $1.29-1.24, \mathrm{~m}$ & 15,16 & & 14 & 29.0-28.3, $\mathrm{CH}_{2}$ & $1.30-1.24, \mathrm{~m}$ & & \\
\hline $15 \mathrm{a}$ & 26.0-25.6, $\mathrm{CH}_{2}$ & $1.45-1.43, \mathrm{~m}$ & & $15 b, 16 a, 16 b$ & $15 \mathrm{a}$ & 25.9-25.6, $\mathrm{CH}_{2}$ & $1.45-1.43, \mathrm{~m}$ & & $15 b, 16 a, 16 b$ \\
\hline $15 b$ & & $1.36-1.34, \mathrm{~m}$ & & $15 a, 16 a, 16 b$ & $15 b$ & & $1.36-1.34, \mathrm{~m}$ & 14 & $15 a, 16 a, 16 b$ \\
\hline $16 \mathrm{a}$ & $37.9-37.8, \mathrm{CH}_{2}$ & $1.72-1.70, \mathrm{~m}$ & & $\begin{array}{l}15 a, 15 b, 16 b \\
17\end{array}$ & $16 \mathrm{a}$ & $37.9-37.8, \mathrm{CH}_{2}$ & $1.72-1.70, \mathrm{~m}$ & & $\begin{array}{l}\text { 15a, 15b, 16b, } \\
17\end{array}$ \\
\hline $16 b$ & & $1.63-1.60, \mathrm{~m}$ & 17 & $\begin{array}{l}15 a, 15 b, 16 a \\
17\end{array}$ & $16 \mathrm{~b}$ & & $1.63-1.60, \mathrm{~m}$ & 17 & $\begin{array}{l}15 a, 15 b, 16 a \\
17\end{array}$ \\
\hline 17 & $64.9-64.8, \mathrm{CH}$ & $4.01, \mathrm{~m}$ & & $\begin{array}{l}16 \mathrm{a}, 16 \mathrm{~b}, 18 \mathrm{a} \\
18 \mathrm{~b}\end{array}$ & 17 & $64.9, \mathrm{CH}$ & $4.01, \mathrm{~m}$ & & $\begin{array}{l}16 a, 16 b, 18 a, \\
18 b\end{array}$ \\
\hline $18 \mathrm{a}$ & $37.9-37.8, \mathrm{CH}_{2}$ & $1.72-1.70, \mathrm{~m}$ & & $\begin{array}{l}17,18 b, 19 a \\
19 b\end{array}$ & $18 \mathrm{a}$ & $37.9-37.8, \mathrm{CH}_{2}$ & $1.72-1.70, \mathrm{~m}$ & & $\begin{array}{l}17,18 b, 19 a \\
19 b\end{array}$ \\
\hline $18 \mathrm{~b}$ & & $1.63-1.60, \mathrm{~m}$ & 17 & $\begin{array}{l}17,18 a, 19 a \\
19 b\end{array}$ & $18 \mathrm{~b}$ & & $1.63-1.60, \mathrm{~m}$ & 17 & $\begin{array}{l}17,18 a, 19 a, \\
19 b\end{array}$ \\
\hline $19 a$ & $26.0-25.6, \mathrm{CH}_{2}$ & $1.45-1.43, \mathrm{~m}$ & & $18 \mathrm{a}, 18 \mathrm{~b}, 19 \mathrm{~b}$ & $19 \mathrm{a}$ & 25.9-25.6, $\mathrm{CH}_{2}$ & $1.45-1.43, \mathrm{~m}$ & & $18 \mathrm{a}, 18 \mathrm{~b}, 19 \mathrm{~b}$ \\
\hline $19 b$ & & $1.36-1.34, \mathrm{~m}$ & 22 & $18 \mathrm{a}, 18 \mathrm{~b}, 19 \mathrm{a}$ & $19 b$ & & $1.36-1.34, \mathrm{~m}$ & 20 & $18 \mathrm{a}, 18 \mathrm{~b}, 19 \mathrm{a}$ \\
\hline 20 & $29.0-28.5, \mathrm{CH}_{2}$ & $1.29-1.24, \mathrm{~m}$ & $\begin{array}{l}18,19,21,22 \\
23\end{array}$ & & 20 & $29.0-28.3, \mathrm{CH}_{2}$ & $1.30-1.24, \mathrm{~m}$ & 21 & \\
\hline 21 & 30.7, $\mathrm{CH}_{2}$ & $1.25, \mathrm{~m}$ & 22,23 & & 21 & $30.7, \mathrm{CH}_{2}$ & $1.30, \mathrm{~m}$ & 20,22 & 23 \\
\hline 22 & 22.0, $\mathrm{CH}_{2}$ & $1.28, \mathrm{~m}$ & $19,20,21,23$ & 23 & 22 & $22.0-21.9, \mathrm{CH}_{2}$ & $1.28, \mathrm{~m}$ & 23 & 23 \\
\hline 23 & 13.9, $\mathrm{CH}_{3}$ & $0.86, \mathrm{t}(6.9)$ & 21,22 & 22 & 23 & $13.9-13.8, \mathrm{CH}_{3}$ & $0.86, \mathrm{t}(7.2)$ & 21,22 & 21,22 \\
\hline 24 & $35.1, \mathrm{CH}_{2}$ & $2.40, \mathrm{t}(7.7)$ & $4,5,6,25,26$ & $4,6,25$ & 24 & $35.1, \mathrm{CH}_{2}$ & $2.40, \mathrm{~m}$ & $4,5,6,25$ & 25 \\
\hline 25 & $30.7, \mathrm{CH}_{2}$ & $1.49, \mathrm{~m}$ & 24,26 & 24,26 & 25 & $30.6, \mathrm{CH}_{2}$ & $1.50, \mathrm{~m}$ & 26 & 24,26 \\
\hline 26 & $28.3, \mathrm{CH}_{2}$ & $1.27, \mathrm{~m}$ & $25,27,28$ & 25 & 26 & $28.2^{b}, \mathrm{CH}_{2}$ & $1.31, \mathrm{~m}$ & & 25,27 \\
\hline 27 & 29.0-28.5, $\mathrm{CH}_{2}$ & $1.29-1.24, \mathrm{~m}$ & $25,26,28,29$ & & 27 & 24.8-24.5, $\mathrm{CH}_{2}$ & $1.57, \mathrm{~m}$ & $26,28,30$ & 26,28 \\
\hline $28 \mathrm{a}$ & $26.0-25.6, \mathrm{CH}_{2}$ & $1.45-1.43, \mathrm{~m}$ & & $28 b, 29 a, 29 b$ & 28 & $47.2-47.1, \mathrm{CH}_{2}$ & $2.19, \mathrm{~m}$ & $\begin{array}{l}27,29,30 \\
31\end{array}$ & 27 \\
\hline $28 \mathrm{~b}$ & & $1.36-1.34, \mathrm{~m}$ & & $28 \mathrm{a}, 29 \mathrm{a}, 29 \mathrm{~b}$ & 29 & $97.2, \mathrm{C}$ & & & \\
\hline $29 a$ & $37.9-37.8, \mathrm{CH}_{2}$ & $1.72-1.70, \mathrm{~m}$ & & $\begin{array}{l}28 \mathrm{a}, 28 \mathrm{~b}, 29 \mathrm{~b} \\
30\end{array}$ & 30 & 47.2-47.1, $\mathrm{CH}_{2}$ & $2.19, \mathrm{~m}$ & $\begin{array}{l}27,28,29 \\
31\end{array}$ & 31 \\
\hline $29 b$ & & $1.63-1.60, \mathrm{~m}$ & 30 & $\begin{array}{l}28 \mathrm{a}, 28 \mathrm{~b}, 29 \mathrm{a} \\
30\end{array}$ & 31 & $24.8-24.5, \mathrm{CH}_{2}$ & $1.57, \mathrm{~m}$ & 28,30 & 30 \\
\hline 30 & $64.9-64.8, \mathrm{CH}$ & $4.01, \mathrm{~m}$ & & $\begin{array}{l}29 a, 29 b, 31 a, \\
31 b\end{array}$ & 32 & 29.0-28.3, $\mathrm{CH}_{2}$ & $1.30-1.24, \mathrm{~m}$ & 33 & \\
\hline $31 \mathrm{a}$ & $37.5, \mathrm{CH}_{2}$ & $1.72-1.70, \mathrm{~m}$ & & $30,31 b$ & 33 & $29.0-28.3, \mathrm{CH}_{2}$ & $1.30-1.24, \mathrm{~m}$ & 32 & \\
\hline $31 b$ & & $1.63-1.60, \mathrm{~m}$ & 30 & $30,31 \mathrm{a}$ & 34 & 31.1, $\mathrm{CH}_{2}$ & $1.26, \mathrm{~m}$ & 33 & 36 \\
\hline $32 \mathrm{a}$ & 28.1, $\mathrm{CH}_{2}$ & $1.41, \mathrm{~m}$ & & & 35 & $22.0-21.9, \mathrm{CH}_{2}$ & $1.28, \mathrm{~m}$ & 36 & 36 \\
\hline $32 b$ & & $1.31, \mathrm{~m}$ & & & 36 & $13.9-13.8, \mathrm{CH}_{3}$ & $0.86, \mathrm{t}(7.2)$ & 34,35 & 34,35 \\
\hline 33 & 21.7, $\mathrm{CH}_{2}$ & $1.28, \mathrm{~m}$ & $31,32,34$ & 34 & & & & & \\
\hline 34 & 13.9, $\mathrm{CH}_{3}$ & $0.87, \mathrm{t}(7.3)$ & 32,33 & 33 & & & & & \\
\hline
\end{tabular}

${ }^{a}$ From proton to the indicated carbon. ${ }^{b}$ From HSQC-TOCSY data. 


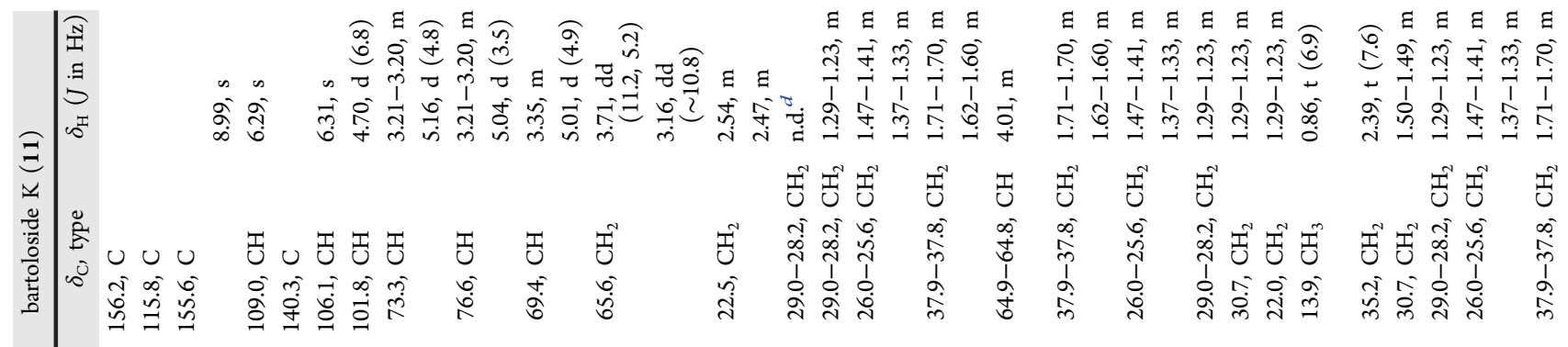
気 |

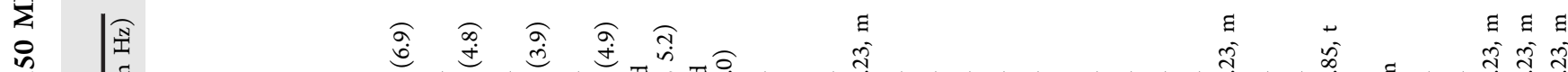

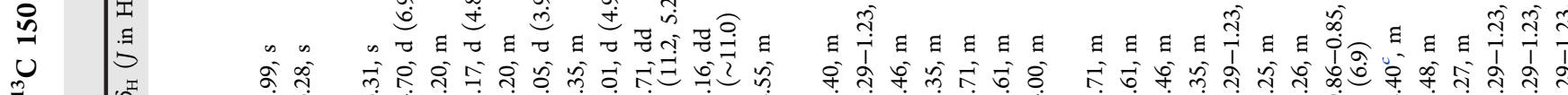

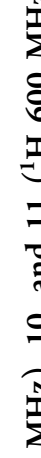

\section{8}

s.

,

\section{s.}

I

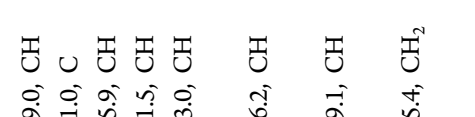

\section{㝴}

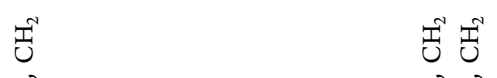

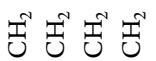

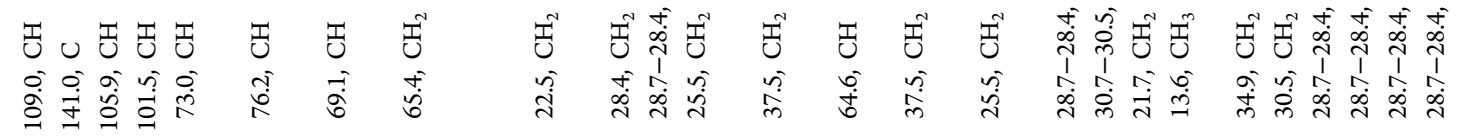

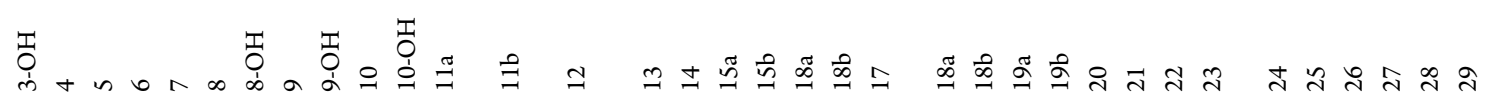

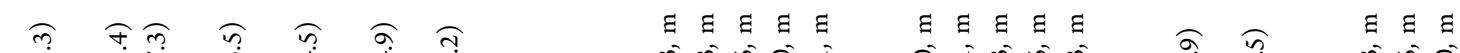

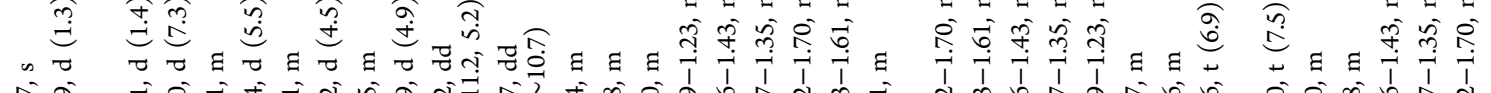

की

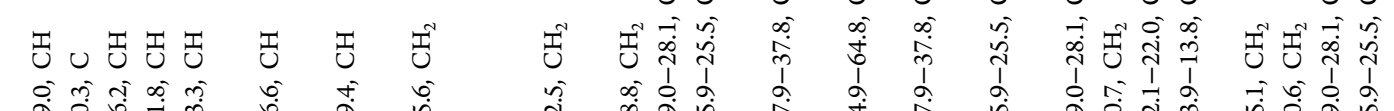

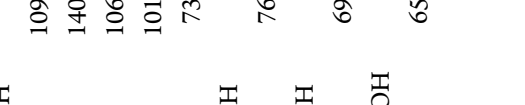
盯

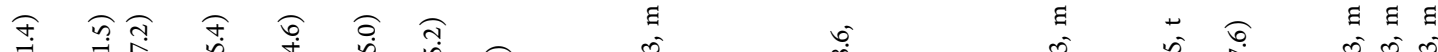
尫

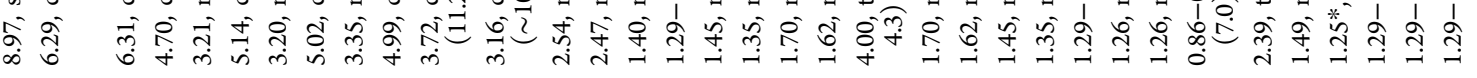

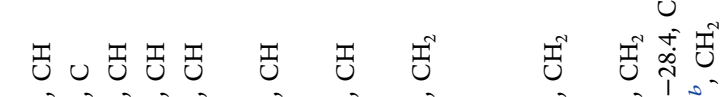<smiles>C1CCC2CCCC2C1</smiles>

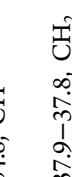

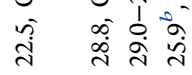

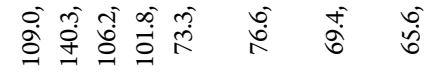
ते ते वें के

\section{预 苟}

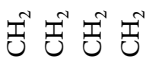

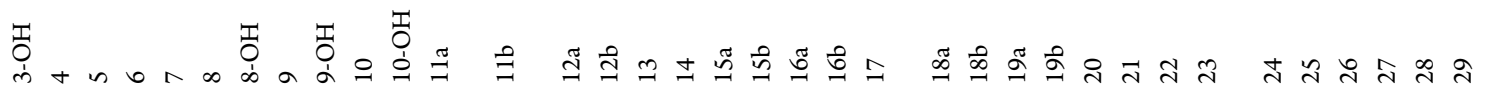

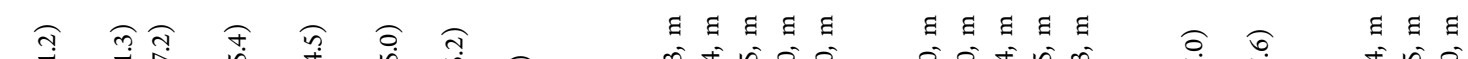

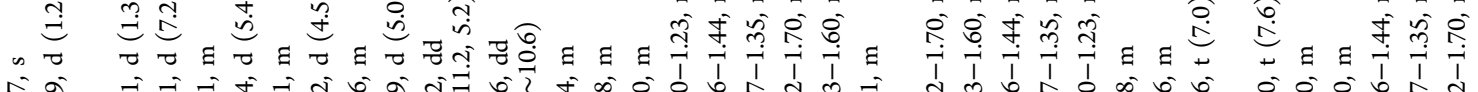

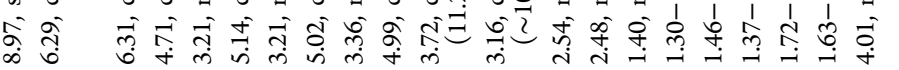




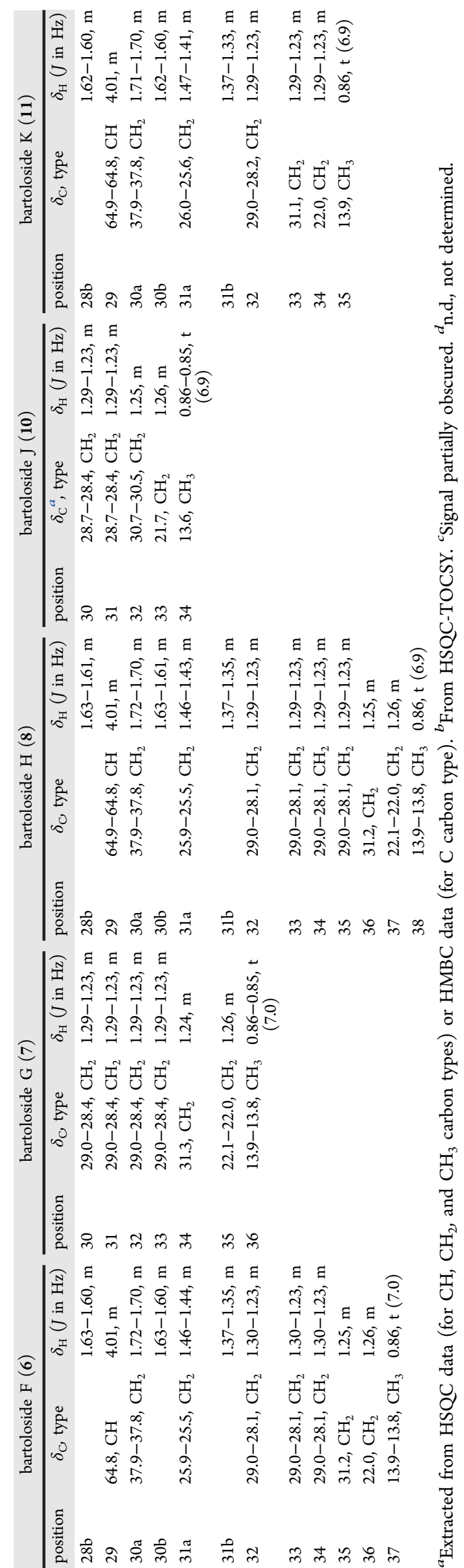

The purified amplicon was ligated to a pGEM-T Easy Vector (Promega) using T4 DNA ligase and the resulting construct was cloned onto chemically competent $E$. coli TOP 10 cells (Life Technologies), purified from a $5 \mathrm{~mL}$ culture of transformed $E$. coli cells (GenElute plasmid miniprep kit, Sigma-Aldrich), and sequenced using M13 primers by Sanger Technology (GATC Biotech). The resulting sequence showed high similarity ( $82 \%$ identity) to a portion of the brtCD region from S. salina LEGE $06155 .^{5}$

Genome Sequencing, Identification, and Annotation of the brt Gene Cluster. Total genomic DNA was isolated from a fresh pellet of a S. salina LEGE 06099 culture using a CTAB-chloroform/ isoamyl alcohol-based protocol. ${ }^{24}$ The gDNA was first fragmented using the AB Library Builder System (Applied Biosystems) and subsequently submitted for sequencing on the Ion Torrent PGM (ThermoFisher Scientific) platform. After sequencing, the reads were evaluated for quality using FastQ $\mathrm{C}^{25}$ followed by assembling with SPAdes version 3.7.0. ${ }^{26}$ Using the BLAST algorithm and the Geneious software package, the generated contigs were queried with the PCRderived brtCD sequence obtained from S. salina LEGE 06099 (see above), which was found ( $100 \%$ identity) within a $106.5 \mathrm{~kb}$ contig. The genomic context of these genes was annotated manually, by using the predicted ORFs as queries in blast searches against the NCBI nucleotide and protein databases (Table S2). The boundaries of the brt gene cluster were defined by the high similarity of flanking genes to the genomes of the closely related Synechocystis sp. strains PCC 6803 and PCC 6714 (Table S2). The annotated nucleotide data have been deposited in GenBank under accession number KX083339.

Cytotoxicity Assays. The evaluation of the cytotoxic activity of chromatographic fractions and pure compounds was performed on the human cancer cell lines T47D (breast carcinoma cells), RKO (colon carcinoma cells), and MG-63 (osteosarcoma cells) at $30 \mu \mathrm{g} / \mathrm{mL}$ (fractions) or dilutions from 50 to $0.003 \mu \mathrm{g} / \mathrm{mL}$ (pure compounds). $\mathrm{IC}_{50}$ values were determined from dose-response curves using the software GraphPad Prism v6.0 (GraphPad Software). Cells were cultured in Dulbecco's modified Eagle medium (DMEM Glutamax, Gibco), supplemented with $10 \%$ (v/v) fetal bovine serum (Gibco), $2.5 \mu \mathrm{g} / \mathrm{mL}$ fungizone (Gibco), $100 \mathrm{IU} / \mathrm{mL}$ penicillin, and $100 \mu \mathrm{g} / \mathrm{mL}$ streptomycin (Pen.Step, Gibco). Cells were preinoculated for $24 \mathrm{~h}$ $\left(37{ }^{\circ} \mathrm{C} ; 5 \% \mathrm{CO}_{2}\right)$ in 96-well plates at a concentration of $3.3 \times$ $10^{4}$ cells $/ \mathrm{mL}$ for cell adhesion. An exposure to the fractions and compounds was then carried out for $48 \mathrm{~h}$. For the determination of cell viability, exposed cells were incubated for $3 \mathrm{~h}$ with $0.5 \mathrm{mg} / \mathrm{mL}$ $\mathrm{MTT}$, and the resulting purple-colored formazan salts were dissolved in $100 \mu \mathrm{L}$ of DMSO. The absorbance was measured at $550 \mathrm{~nm}$ in a microplate reader (Synergi HT, Biotek). All tests were run in triplicate and averaged.

\section{ASSOCIATED CONTENT}

S Supporting Information

The Supporting Information is available free of charge on the ACS Publications website at DOI: 10.1021/acs.jnatprod.6b00351.

NMR data for 1, NMR spectra for all compounds, annotated HRESIMS ${ }^{n}$ data, phylogenetic analysis of the cyanobacterium strain, details on primer design, and annotation of the brt gene cluster (PDF)

\section{AUTHOR INFORMATION}

\section{Corresponding Author}

*Tel (P. N. Leão): +351 2234018 14. Fax: +351 223390608. E-mail: pleao@ciimar.up.pt.

\section{Present Address}

${ }^{\perp}$ Faculty of Pharmaceutical Sciences, University of Iceland, Hagi, Hofsvallagata 53, IS-107, Reykjavik, Iceland.

\section{Notes}

The authors declare no competing financial interest. 


\section{ACKNOWLEDGMENTS}

We would like to thank CEMUP for NMR and HRMS analyses, I. Dias, A. Kijoa, and S. Buttachon for optical rotation measurements, and B. Jarrais for IR measurements. This work was supported by Fundação para a Ciência e a Tecnologia (FCT) through grants PTDC/MAR-BIO/2818/2012 and IF/ $01358 / 2014$ to P.N.L. and partially by project NOVELMAR (NORTE-01-0145-FEDER-000035) supported by the NORTE2020 Program and the European Regional Development Fund.

\section{REFERENCES}

(1) Jordan, P.; Fromme, P.; Witt, H. T.; Klukas, O.; Saenger, W.; Krauß, N. Nature 2001, 411, 909-917.

(2) Wada, H.; Murata, N. In Lipids in Photosynthesis: Structure, Function and Genetics; Paul-André, S., Norio, M., Eds.; Advances in Photosynthesis and Respiration; Springer: The Netherlands, 1998; pp $65-81$.

(3) Balogi, Z.; Török, Z.; Balogh, G.; Jósvay, K.; Shigapova, N.; Vierling, E.; Vígh, L.; Horváth, I. Arch. Biochem. Biophys. 2005, 436, 346-354.

(4) Flores, E.; Herrero, A. Nat. Rev. Microbiol. 2010, 8, 39-50.

(5) Leão, P. N.; Nakamura, H.; Costa, M.; Pereira, A. R.; Martins, R.; Vasconcelos, V.; Gerwick, W. H.; Balskus, E. P. Angew. Chem., Int. Ed. 2015, 54, 11063-11067.

(6) Brito, A.; Ramos, V.; Seabra, R.; Santos, A.; Santos, C. L.; Lopo, M.; Ferreira, S.; Martins, A.; Mota, R.; Frazão, B.; Martins, R.; Vasconcelos, V. Syst. Appl. Microbiol. 2012, 35, 110-119.

(7) Kleigrewe, K.; Almaliti, J.; Tian, I. Y.; Kinnel, R. B.; Korobeynikov, A.; Monroe, E. A.; Duggan, B. M.; Di Marzo, V.; Sherman, D. H.; Dorrestein, P. C.; Gerwick, L.; Gerwick, W. H. J. Nat. Prod. 2015, 78, 1671-1682.

(8) Preisitsch, M.; Niedermeyer, T. H. J.; Heiden, S. E.; Neidhardt, I.; Kumpfmüller, J.; Wurster, M.; Harmrolfs, K.; Wiesner, C.; Enke, H.; Müller, R.; Mundt, S. J. Nat. Prod. 2016, 79, 106-115.

(9) Marquez, B. L.; Watts, K. S.; Yokochi, A.; Roberts, M. A.; Verdier-Pinard, P.; Jimenez, J. I.; Hamel, E.; Scheuer, P. J.; Gerwick, W. H. J. Nat. Prod. 2002, 65, 866-871.

(10) Luesch, H.; Yoshida, W. Y.; Moore, R. E.; Paul, V. J.; Mooberry,

S. L. J. Nat. Prod. 2000, 63, 611-615.

(11) Milligan, K. E.; Marquez, B. L.; Williamson, R. T.; Gerwick, W. H. J. Nat. Prod. 2000, 63, 1440-1443.

(12) Bui, H. T. N.; Jansen, R.; Pham, H. T. L.; Mundt, S. J. Nat. Prod. 2007, 70, 499-503.

(13) Gerth, K.; Steinmetz, H.; Höfle, G.; Jansen, R. Angew. Chem., Int. Ed. 2008, 47, 600-602.

(14) Dembitsky, V. M.; Srebnik, M. Prog. Lipid Res. 2002, 7, 31536710.1016/S0163-7827(02)00003-6.

(15) Pratter, S. M.; Ivkovic, J.; Birner-Gruenberger, R.; Breinbauer, R.; Zangger, K.; Straganz, G. D. ChemBioChem 2014, 15, 567-574.

(16) Jungmann, K.; Jansen, R.; Gerth, K.; Huch, V.; Krug, D.; Fenical, W.; Müller, R. ACS Chem. Biol. 2015, 10, 2480-2490.

(17) Preisitsch, M.; Heiden, S.; Beerbaum, M.; Niedermeyer, T.; Schneefeld, M.; Herrmann, J.; Kumpfmüller, J.; Thürmer, A.; Neidhardt, I.; Wiesner, C.; Daniel, R.; Müller, R.; Bange, F.-C.; Schmieder, P.; Schweder, T.; Mundt, S. Mar. Drugs 2016, 14, 21.

(18) Weise, G.; Drews, G.; Jann, B.; Jann, K. Arch. Microbiol. 1970, 71, 89-98.

(19) Keleti, G.; Sykora, J. L. Appl. Environ. Microbiol. 1982, 43, 104109.

(20) Murata, N.; Siegenthaler, P.-A. In Lipids in Photosynthesis: Structure, Function and Genetics; Paul-André, S., Norio, M., Eds.; Advances in Photosynthesis and Respiration; Springer: The Netherlands, 1998; pp 1-20.

(21) Higashi, S.; Murata, N. Plant Physiol. 1993, 102, 1275-1278.

(22) Kotai, J. Nor. Inst. Water Res. Blindern Oslo 1972, 11/69, 5.
(23) Augusti, D. V.; Carazza, F.; Augusti, R.; Tao, W. A.; Cooks, R. G. Anal. Chem. 2002, 74, 3458-3462.

(24) Singh, S. P.; Rastogi, R. P.; Häder, D.-P.; Sinha, R. P. World J. Microbiol. Biotechnol. 2011, 27, 1225-1230.

(25) Andrews, S. 2010, Available online, http://www.bioinformatics. babraham.ac.uk/projects/fastqc.

(26) Bankevich, A.; Nurk, S.; Antipov, D.; Gurevich, A. A.; Dvorkin, M.; Kulikov, A. S.; Lesin, V. M.; Nikolenko, S. I.; Pham, S.; Pribelski, A. D.; Pyshkin, A. V.; Sirotkin, A. V.; Vyahhi, N.; Tesler, G.; Alekseyev, M. A.; Pevzner, P. A. J. Comput. Biol. 2012, 19, 455-477. 